\title{
THE TRADE GOVERNANCE FRAMEWORK PROVIDED BY TRIPS AND CLAIM OF 'PRO-DEVELOPMENT'AGENDA
}

\author{
Karina Dwi Nugrahanti Putri* \\ Business Law Department, Faculty of Law, Universitas Gadjah Mada \\ Jalan Sosio Yustisia, Bulaksumur, Depok, Sleman, D.I. Yogyakarta 55281
}

\begin{abstract}
Having encountered objection from developing countries during previous negotiations, the WTO has tried to soften the framework of trade liberalisation in subsequent negotiations, held in Doha in 2001. In this round, the WTO gave rise to the 'pro-development framework' to attract fuller participation by developing countries. However, the development agenda had been assumed as a strategy in maintaining the superiority of advanced industrialised countries in applying 'organised imbalance. This essay will discuss the implementation of special and differential treatment (SDT) for developing countries within TRIPS provisions. The promise of help through SDT for developing countries (as the majority of importer country of patented rights) is merely used as the medium with which to prioritise MNCs from developed countries which operate in developing countries.
\end{abstract}

Keywords: WTO, developing countries, special and differential treatment, Doha Round.

\section{Intisari}

Setelah mendapatkan pertentangan dari negara-negara berkembang dalam putaran negosiasi sebelumnya, pada Putaran Doha (Doha Round) WTO merespon dengan memperkenalkan konsep framework perdagangan bebas baru yang dinilai lebih lunak. Pada putaran Doha, WTO meluncurkan konsep 'prodevelopment framework' untuk menarik partisipasi dari negara berkembang. Akan tetapi, hal ini dianggap sebagai strategi negara maju untuk mempertahankan dominasi mereka di dalam sistem WTO. Tulisan ini akan membahas bagaimana implementasi dari Special and Differential Treatment (SDT) didalam aturan Trade Related aspects of Intellectual Property Rights (TRIPS) yang ditujukan untuk negara berkembang. Ide pro-pembangunan yang digadang-gadang sebagai bantuan dalam bentuk SDT bagi negara berkembang (sebagai mayoritas pengimpor produk-produk intelektual), dinilai sebagai kedok untuk melayani kepentingan perusahaan multi nasional (PMN) yang banyak beroperasi di negara-negara tersebut.

Kata Kunci: WTO, negara berkembang, special and differential treatment, Doha Round.

\section{Pokok Muatan}

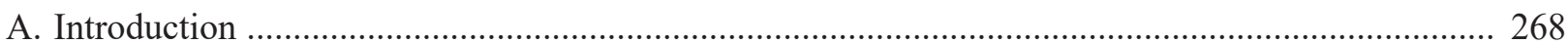

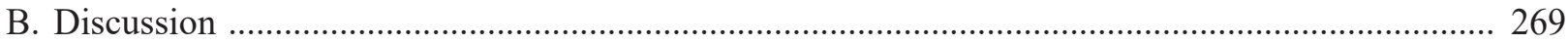

1. Pro-development in the Trade Governance Framework ............................................................ 269

2. Why the Pro-development Framework is Problematic ............................................................... 271

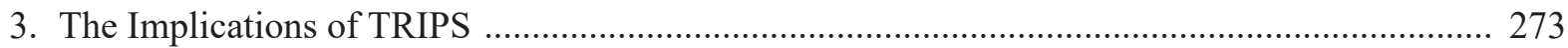

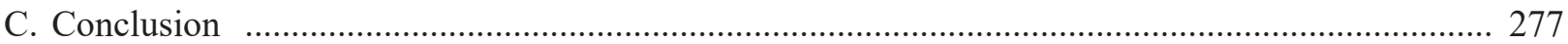




\section{A. Introduction}

Since 1995, the World Trade Organisation (WTO) has had a strong influence on global trade regimes. They administers trade agreements, organise the forum for trade negotiations, handle trade disputes, monitors trade disputes, monitors national trade policies, provides technical assistance and trains developing countries to co-operate with other international institutions. ${ }^{1}$ The last mission of WTO, which is integrating developing countries in the framework, can be seen as the most challenging issue in the WTO. ${ }^{2}$ Historically, the developing world was dissatisfied with General Agreements on Tariffs and Trade (GATT), as previous institution before WTO. Developing countries felt that they have little influence in GATT outcomes, especially in term of decision-making process. Developing countries believe that the decision making process in the GATT (WTO today), were exclusively decided by a smaller group of countries. The decision making process was done before an issue is brought to the table, where the rest of the decision making process is about convincing the rest of the group about that decision. In this sense, developing countries felt excluded and not given adequate consideration. Therefore, developing countries are reluctant to participate in round, which may raise more obligations that they must meet. ${ }^{3}$

At the end of the Uruguay Round in 1994, the view on future rounds were splitted. In one hand, there was a considerable pessimism about the prospects for the next round (the ninth round). Many scholars expressed the view that the era of rounds was over, that the world could no longer wait for ten or more years between rounds to solve pressing and fast changing problems of international economic relations. The saturated discussion between members in the rounds rose a discourse that they should embrace another possibilities to different techniques of negotiation and rule making for the international trading system. On the other hand, some of the advantages of rounds continued to be pointed out-for example a round often provides more trading material in the sense that different nations have different objectives and may be more willing to yield in certain areas. ${ }^{4}$

The $9^{\text {th }}$ WTO ministerial meeting in Seattle in December 1999 failed after a week-long-streetprotests caught global media attention. The events in Seattle can be referred as the tragedy of WTO, when the public started to radically question the functions of WTO. There are 2 types of tensions/ problems happened in Seattle, inside problem and outside problem. The inside problem referred to the deadlock between delegates in discussing a widearray of old and new issues such as agriculture, the position of developing countries, the question of which new issues to deal with whether to launch a full new round or deal with different issues one at a time. While at the outside, the demonstrations provided more tension because of the NonGovernmental Organisatons (NGOs) and public participation against the round. They demand WTO clarify the issues of transparency and participation in dispute settlement, negotiations and decisionmaking mechanisms. Consequently, developing countries pressed for special treatment in GATT and attempted to create new rules (which are not based on GATT) to embody their concept of how the world economy should operate. ${ }^{5}$

Having encountered dissatisfaction from developing countries during previous negotiations on trade liberalisation, the WTO has tried to soften the framework of trade liberalisation in the subsequent negotiations, held in Doha in 2001 (the $10^{\text {th }}$ round). ${ }^{6}$ Therefore, the 'pro-development

World Trade Organization, "Special and Differential Treatment Provisions", https://www.wto.org/english/tratop_e/devel_e/dev_special_ differential provisions e.htm, accesssed in 8 November 2018.

John H. Jackson, et al., 2013, Legal Problems of International Economic Relations, West Academic Publishing, Minnesota, p. 1269.

John H. Jackson, Op. cit., p. 1282.

John H. Jackson, Op. cit., p. 253.

Ibid.

Clive George, 2010, The Truth about Trade: The Real Impact of Liberalization, Zed Books, London, p. 97. 
framework was introduced.' ${ }^{7}$ However, even the title of the round was pro-development round, but this round still promotes individual ownership of biodiversity through TRIPS (Trade Related aspect of Intellectual Property Rights). ${ }^{8}$

The TRIPS agreement focuses on and regulates five main IP related concerns: 1). How basic principles of the trading system and other international intellectual property agreements should be applied; 2). How to give adequate protection to intellectual property rights; 3 ). How countries should enforce those rights adequately in their own territories; 4). How to settle disputes on intellectual property between members of the WTO; 5). Special transitional arrangements during the period when the new system is being introduced. ${ }^{9}$ Substantively, the TRIPS Agreement is not only sets out the subject matter to be protected, but also sets out obligations on members, the rights to be conferred, the permissible exceptions to those rights, and the minimum duration of protection. Patent regime as part of the coverage in TRIPS, is facilitating the theft of biological resources and traditional knowledge.

The imposition of patent rights over biological resources and traditional knowledge unfairly deprive communities of their rights over and access to, the same resources they have nurtured and conserved over generations. ${ }^{10}$ The central of the debates are related to requirements of Article 27.3(b) of TRIPS that revolves about the patenting of life and its adverse effects on food security, farmers' livelihoods, local communities' rights, sustainable resource use and access to genetic resources. Patents on seeds and genetic resources for food and agriculture threaten sustainable farming practices, farmers' livelihoods and food security. Farmers using patented seeds are deprived of their right to use, save, plant and sell their seeds. However, the option to protect plant varieties with sui generis system is being reduced to compliance with the International Union for the Protection of New Varieties of Plants (UPOV) convention, through pressure on developing countries from industrialized countries, the global seed and biotechnology company. ${ }^{11}$

Developing countries' attempt to undertake a substantive review of Article 27.3 (b) is at a stalemate. The review process has opened up to the issues of substance but the developed countries are not taking seriously developing country proposals for revision. ${ }^{12}$ This essay will argue that a focus on economic growth in the Doha 'Pro-development' Round, maintains the superiority of advanced industrialised countries in applying 'organised imbalance' between developed and developing countries. ${ }^{13}$ Subsequently, the WTO's development concept marginalises and neglects the interests of developing countries. It explores how TRIPS are problematic in that they create an imbalance position between developed and developing countries. This essay will discuss the implementation of Special and Differential Treatment (SDT) for developing countries within TRIPS provisions. Moreover, unwritten indigenous knowledge as a constraint and unequal bargaining position between public interest and corporate greed in patent regimes, will be used as example of 'development through inequality'. ${ }^{14}$

\section{B. Discussion}

\section{Pro-development in the Trade Governance Framework}

The 'pro-development framework' of the Doha Round is a WTO concept created to attract the participation of developing countries through the

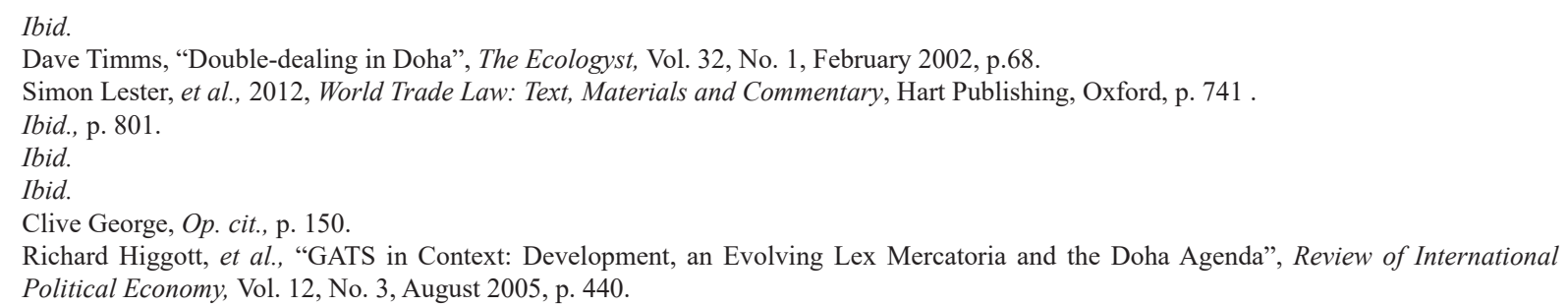


tagline: 'development for developing countries'. ${ }^{15}$ The concept of 'development' by the WTO in this context is premised upon the 'consolidation and entrenchment commercial law' and views people as

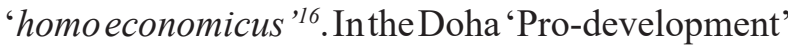
Round, the WTO only offers this "new" conceptual framing of trade negotiation at a rhetorical level. ${ }^{17}$ This new framing perpetuates liberal trade theory with subsequent implementation that reflects commercial law as the normative underpinnings of the 'pro-development framework'. ${ }^{18}$ Through the 'development for developing countries' tagline, the WTO has tried to avoid drawing attention to the social and political struggles of developing countries regarding the mainstreaming of commercial interest within the Doha Round. ${ }^{19}$ These struggles have been overlooked because they may challenge the marketbased policy of the WTO as the regulator of global trade regimes. ${ }^{20}$ In the Doha Round, 'development' has reflected a commitment to modernisation and industrialisation with economic growth as a key indicator. $^{21}$

In the WTO 'pro-development' framework in Doha, the demands from developing countries, who felt unheard in the Uruguay Round, were made a priority. ${ }^{22}$ The Doha Declaration sets a 'comprehensive and determinant' work program titled the "Doha Development Agenda". ${ }^{23}$ This declaration has placed development as central to the aim of trade liberalisation in trying to deliver concrete benefits for members, particularly by assisting developing countries and least developed countries to deal with international trade policy. ${ }^{24}$ This assistance consists of, 'enhancing market access for goods from developing countries, balancing rules regarding trade, technical assistance and capacity building to get benefit from the growth of world trade regime'. ${ }^{25}$ Moreover, to support the 'comprehensive' developmental agenda, the Doha round places poverty reduction as the focus of the WTO's considerations to ensure trade liberalisation stimulates economic development and gives benefit to developing countries. ${ }^{26}$ In this regard, trade liberalisation is assumed to be a necessity for globally sustainable development. ${ }^{27}$

Within the WTO, international trade is the pivotal instrument to enhance economic growth and development, as it will link countries to 'greater market access opportunities, more foreign exchange, more foreign direct investment, better transfer of technology and booster domestic productivity'. ${ }^{28}$ Through international trade, there are conditions of cooperation among nations to fulfill the free market's dynamic (Barral 2006: 217; O'Brien \&

15 Heloise Weber, "Reconstituting the Third World'? Poverty Reduction and Territoriality in Global Politics of Development", Third World Quarterly, Vol. 25, No. 1, 2004, p. 187.

16 Homo economicus is a basic humanity hypothesis of economics, especially neoclassical economics. The Homo economicus hypothesis assumes human behaviors are motivated by instrumental rationality and self-interest. Thus, the decision-making processes are based on the deliberate judgment and calculation of costs and benefits. In addition, individuals are self-interested in interactions, and their sole objective is the maximization of self-interest. See Ziqiang Xin, et al., "Homo Economicus Belief Inhibits Trust", PLoS ONE, Vol. 8, Issue 10, October 2013, pp. 1-5.

Ibid., p. 439.

Ibid., p. 440.

Heloise Weber, Op. cit., p. 187.

Ibid., p. 195.

Richard Higgott, et al., Op. cit., p. 437

J. Michael Finger, "Developing Countries in the WTO System: Applying Robert Hudec's Analysis to the Doha Round", The World Economy, Vol. 31, No. 7, July 2008, p. 888; Surya P Subedi, 2008, International Investment Law: Reconciling Policy and Principle. Hart Publishing, Oxford, p. 427.

23 Joseph M. Senona, "EPAs and the Doha Round: development or discontent”, Journal of International Trade Law and Policy, Vol. 8, No. 1, 2009 , p. 61.

24 Joseph M. Senona, Op. Cit., p. 62

25 Elimma Ezeani, "WTO Post Doha: Trade Deadlocks and Protectionism”, Journal of International Trade Law and Policy, Vol. 12, No. 3, 2009, p. 273.

26 Joseph E. Stiglitz, et al., “A Development-friendly Prioritisation of Doha Round Proposals”, The World Economy, Vol. 28, No. 3, March 2005, p. 293

27 Clive George, Op. it., p. 3

28 Joseph M. Senona, Op. cit., p. 61. 
Williams 2010:21). From a liberal perspective, trade liberalisation will deliver a 'positive-sum game', which benefits everyone. ${ }^{29}$ The underlying theory of this liberalisation is comparative advantage, ${ }^{30}$ which involves international interaction as a source of prosperity. ${ }^{31}$

However, another perspective merely views trade liberalisation as an effort to retain developed countries' domination within the global trade regime. ${ }^{32}$ Moreover, the dominant position of developed countries within WTO negotiation processes will exacerbate the marginal position of developing countries. ${ }^{33}$ Furthermore, more than a decade after the enactment, The Doha Declaration still has resistance from developing countries regarding the provisions of TRIPS, ${ }^{34}$ especially from India as the producer of 'cheaper' pharmaceutical substances. ${ }^{35}$

Regarding TRIPS, India, as the 'alternative' producer, must pay royalties to the patent holder and should limit its medicine usage within the country. ${ }^{36}$ This was created with the aim of respecting the expenditure of research and development divisions of multinational companies (MNCs) as the prior inventor. ${ }^{37}$ In contrast, developing countries' demands for renegotiating TRIPS to protect their traditional medicine and prevent bio-piracy by MNCs were ignored. ${ }^{38}$ Regarding this resistance, the WTO provides 'special and differential treatment' (SDT) provisions as an integral part of all negotiations, including the TRIPS, to assist developing countries in dealing with specific issues. ${ }^{39}$ Moreover, technical assistance from the WTO has intended to help developing countries to comply with multilateral rules, to participate in shaping the body of regulations and the liberalisation process, and to take advantage of their integration into world trade. ${ }^{40}$

\section{Why the Pro-development Framework is Problematic}

Although the WTO tries to shift its position closer to developing countries by being 'prodevelopment' through its SDT provisions, debates around it have never ended. The basic argument for the problematic 'pro-development' framework that has been offered by the WTO, lies in the concept of 'development' itself. ${ }^{41}$ The pro-development framework of the WTO through the Doha Round maintained features of liberalism. ${ }^{42}$ Liberalism is based on several basic concepts. ${ }^{43}$ Among them is how development is correlatively viewed as economic growth, where anyone shares the same potential to develop under 'free trade rules'. ${ }^{44}$ This has been critiqued because the economic focus from a liberal perspective sacrifices other valued elements of international trade such as: the environment, human rights, and conditions of labor. ${ }^{45}$ The economic focus at the core of this liberal perspective has ignored the complexity of human being. ${ }^{46}$

Moreover, the identification of different

\footnotetext{
Robert O’ Brien, et al., 2010, Global Political Economy, London, p. 21.

30 Comparative advantage is one of the principal ideas used in economics to explain the potential profit from international trade. This principle asserts that a country should focus on producing goods, which are relatively more profitable than other goods. Profits follow from specializing in the lowest labour hours and production costs. Moreover, based on this principle, there is no country that does not have comparative advantage. The WTO. ND. Comparative advantage, available at http://www.wto.org/english/res_e/reser_e/cadv_e.htm. 
aspects of everyday lived experience is needed to build the whole picture of 'development'. ${ }^{47}$ The WTO's assumption of development has used 'orthodox development' theories, which, 'perpetuate development through inequality'. ${ }^{48}$ Differences between the orthodox and heterodox approaches to development are also to be found in their differing epistemologies and methodologies of evaluating poverty in world politics. ${ }^{49}$ Together, these distinct premises make for fundamentally different visions of development itself. In his important critique of neo-liberalism, John Broman (1995) traced the affinities between orthodox development theory and classical economic theory in general, focussing on its commitment to the notion of homo economicus and methodological individualism. ${ }^{50}$

As Brohman argued (quoting Albert Hirschman) the role of homo economicus within neoclassical theory is to reduce human beings and their complex social settings to an individual who is a 'rational, self-interested, instrumental maximizer with fixed preferences'. If development concerns processes of human action and interaction rather than just goods and resources, it is important to deepen our understanding of what it is to be human. This necessitates incorporating a hermeneutic component into development studies that addresses how human actions and social relations are linked with intersubjective values and meanings' ${ }^{51}$ While the heterodox challenge exhibits a methodological and epistemo- logical diversity, its various strands converge in their insistence on the significance of the social experiences of the excluded, underprivileged and systematically oppressed within a critique of rationalisation more generally. Their rejection of rationalism's methodological individualism raises the important issue of the historicity of social relations of inequality and harm, and focuses understanding and explanations of the continuities of 'development' on the social and political power relations through which they are sustained, not only rely on economic growth. ${ }^{52}$

In support of this critique, the 'Green Politics Vision' states that development is a concept of an, 'active and autonomous civic association at the heart of democratization projects, to counter the trends that alienate citizens from politics, as well as humans from their natural environments'. ${ }^{53}$ This perspective encompasses environmental and societal conditions that are not considered by the WTO. ${ }^{54}$ Moreover, the liberal development concept that informs the WTO hides the realities of the exploitation of the environment. ${ }^{55}$ The WTO's development conception which prioritises economic interest has been used to neglect environmental protection. ${ }^{56}$ In particular, the exploitation of local people's labour conditions is also hidden. ${ }^{57}$ Unfortunately, this 'hidden transcript' is masked by the 'public transcript' that has been produced by the WTO through the open 'performance' of world economic growth statistics. ${ }^{58}$ This public data hides the fact that some countries benefit from economic growth more than others in terms of how economic growth is used to improve social conditions within a country. ${ }^{59}$ From a liberalisation perspective, economic security is a priority to ensure the interest of corporations as

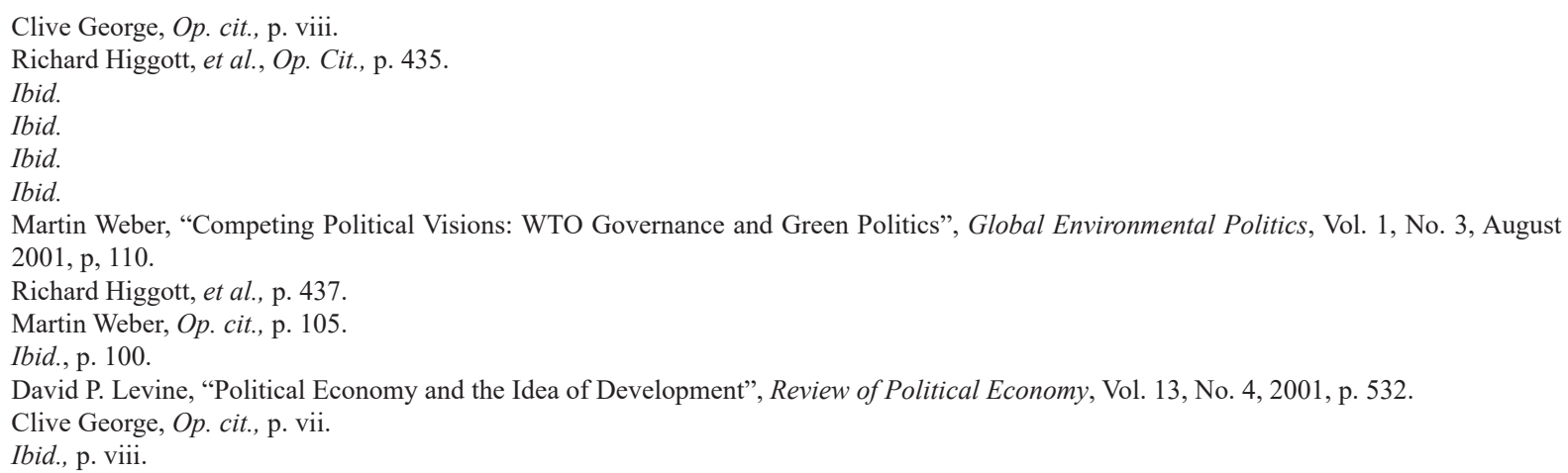


'efficient' large-scale producers, ${ }^{60}$ at the expense of the environment and social conditions.

On the other hand, the WTO promising 'assistance' and 'priority' for developing countries is merely fed into well-established narratives as principles. ${ }^{61}$ Not all of the provisions actually use exact 'special and different treatment, but the common thread is that they offer looser rules for developing countries. In general terms, according to the WTO's website, these provisions offer 'extra time for developing countries to fulfill their commitments; are designed to increase developing countries' trading opportunities through greater market access'; require 'WTO members to safeguard the interest of developing countries when adopting some domestic or international measures; and provide 'various means of helping developing countries' ${ }^{62}$ 'Even though, there are many provisions in the WTO Agreement that provide 'special and differential' treatment for developing countries, the drafts are in fairly vague terms, leaving the scope of the obligation somewhat unclear'. ${ }^{63}$

Therefore, the SDT benefits the political image of advanced developed countries rather than making a significant difference in benefitting developing countries. ${ }^{64}$ Developed countries have been reluctant to commit to anything more than a symbolic commitment and utilize SDT policies to make a formal contribution to developing countries. ${ }^{65}$ Take an example of the most controversial issues of TRIPS is the prices of pharmaceuticals in developing countries. The issue has been particularly prominent with regard to HIV/AIDS medications. As TRIPS obligations phased in for developing countries and they were required to give effect to all pharmaceutical patients, including process patents, the prices of certain HIV/AIDS medications either rose or were expected to rise dramatically, raising the concern that poor patients in developing countries affected by HIV/AIDS pandemic would have no hope of affording them. There is a strategy to manage this issue through compulsory licenses. Yet, the requirement that production under a compulsory license be 'predominantly' for the domestic market of the country that issues the license poses a potential problem. Developing countries without technical capacity to manufacture might seem to be foreclosed from the compulsory license option by this principle. ${ }^{66}$

\section{The Implications of TRIPS}

As a feature of the 'pro-development' framework, TRIPS have created a great imbalance between the producers of intellectual property rights (IPR) and importing IPR countries. ${ }^{67}$ The failure to resolve the availability of compulsory licensing exceptions to patent protection for countries suffering a public health crisis with insufficient or no manufacturing capabilities tempered the success of the Declaration. Therefore, the hidden transcript of TRIPS and how development and trade liberalization are realised becomes a process where instead of helping developing countries to achieve benefits from trade liberalisation, technical assistance is merely used by developed countries to emphasize intellectual property protection for foreign corporations holders operating in developing countries. ${ }^{68}$ Moreover, the enhancing of IPR protection of developed countries has

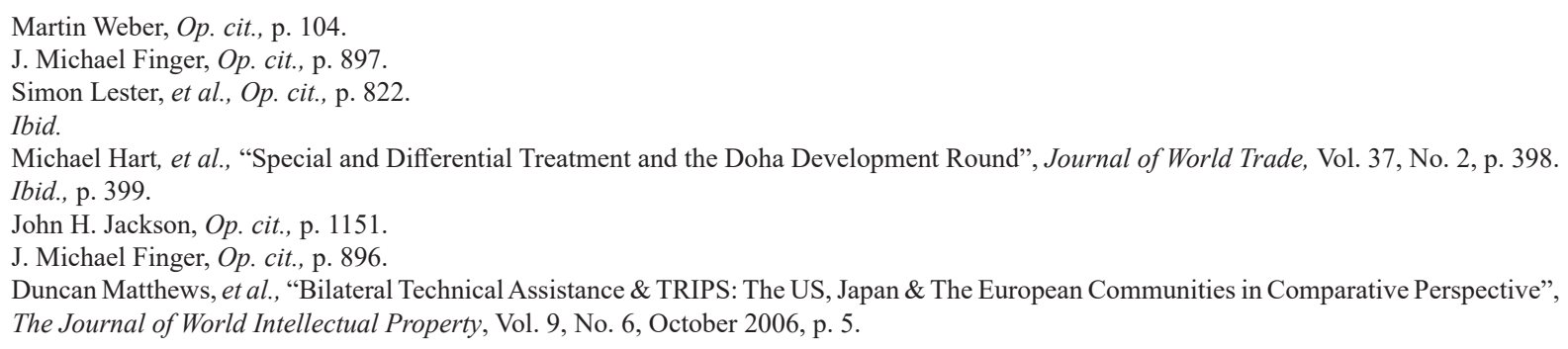


been used to convince these developing countries not to use their privileges on SDT principles ${ }^{69}$ including longer time periods for implementing agreements and commitments. ${ }^{70}$ Another privilege for developing countries is the obligation from developed countries for compulsory licensing and parallel importation regarding public health, which may reduce the profit of the innovator from patent holding. ${ }^{71}$ With compulsory licensing, developing countries can be exempt from the exclusive rights covered by patent to produce similar goods, whilst compulsory licensing gives ease to developing countries to import goods sold locally from cheaper overseas sources. $^{72}$

From a developing country's perspective, income for developed countries as a patent holder may decrease; yet it does not decrease significantly compared to the extra profits from the 'monopoly' practices through the patent regime. ${ }^{73}$ For example, the United States' gain is thirteen times larger than the 'incentive' that they have lost by the compulsory licensing and parallel importation. ${ }^{74}$ Moreover, the incentive fee for innovators ignores the fact that the higher price of patented products has added burden to the users, which vastly comes from developing countries. ${ }^{75}$ The distinctive results from stricter TRIPS are inevitable; there are some benefits for the producing states, but at the same time, it may spread difficulties and exacerbate the limited conditions of the importing countries. ${ }^{76}$ In the Doha Round, relaxation of certain provisions ofTRIPS agreements has been a priority of developing countries..$^{77}$ This comes from the underlying rationale that most developing countries merely act as importers of IPR. ${ }^{78}$ Thus, the IPR regime in TRIPS creates drawbacks for importers by increasing the price of patented products and preventing citizens having easy access to any patented medicine. ${ }^{79}$ This shows that development implications within TRIPS are not beneficial to developing countries since they only prioritise corporations and privatisation. The basic rationale for TRIPS is protecting individuals' rights, not community as discussed above, as an important part of 'person' in developing countries. More broadly, this is because of the particular conception of development that informs the WTO which is one that priorities neoliberal principles, primarily that of economic growth.

TRIPS, which have been claimed to balance private interest and public goods, face resistance from most developing countries. ${ }^{80}$ TRIPS has in fact, given multilateral trade system a bad name. Contrary to the so-called free trade and trade liberalization principles of the WTO, TRIPS is being used as a protectionist instrument to promote corporate monopolies over technologies, seeds, genes, and medicines. Through TRIPS, large corporations use intellectual property rights to protect their market and to limit competition. ${ }^{81}$ In establishing an IPR regime, multinational companies (on behalf of private interest) have been given the right to monopolise profit from production and distribution at the cost of all citizens worldwide, particularly in developing countries. ${ }^{82}$ One interesting illustration of the IPR issue can be found in pharmaceutical patents. The countries which exclude medicine

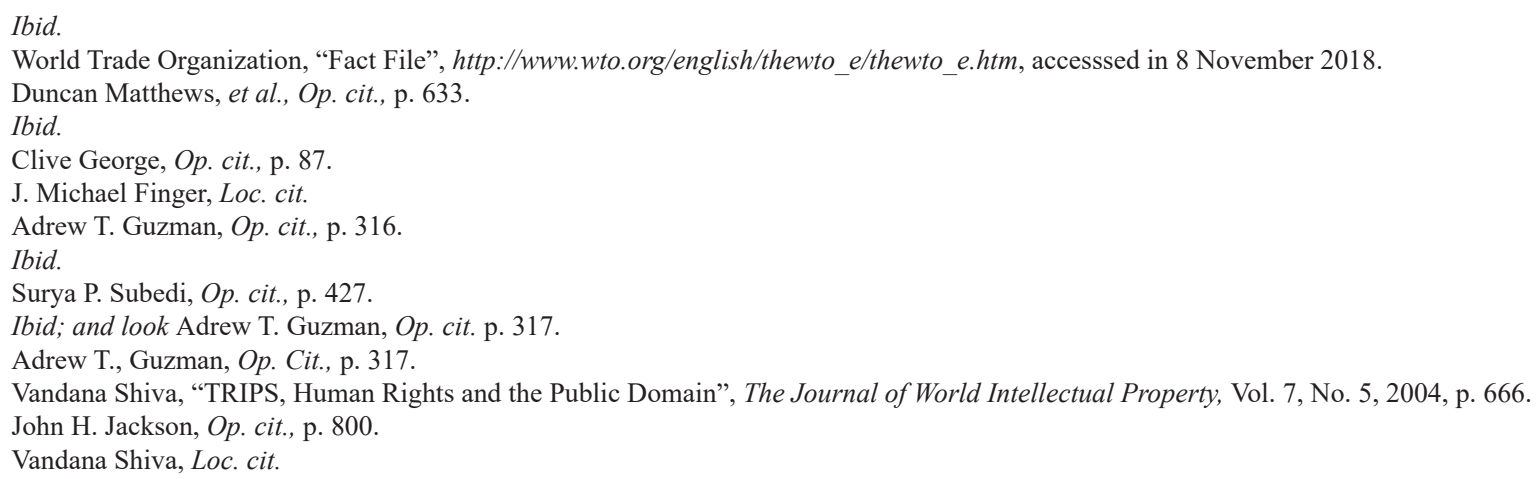


from the patent system are able to produce cheaper medicine and avoid heavy dependence on imports. ${ }^{83}$ This is acknowledged by the dominant medicine holders (developed countries as the first 'inventor') to enforce TRIPS to implement the provision of exclusive marketing rights to protect their market share on targeted regions. ${ }^{84}$ Therefore, preventing cheaper medicine access and increasing the price of patented medicine is indicative of spreading disease for developing countries, rather than curing it. ${ }^{85}$

Preventing cheaper medicine access is not parallel with the conception of development prioritised in the Doha pro-development round. ${ }^{86}$ This condition merely preserves the aim of the privatisation of health services and the monopoly on knowledge, which prioritises private interests dominated by MNCs rather than public interest. ${ }^{87}$ Through TRIPS, health is interpreted as a privatisation potential, through the WTO's neoliberal development strategy. ${ }^{88}$ This because the neoliberal development strategy tries to promote economic growth through structural adjustment of national economies and the liberalisation of trade to fulfill market based logic. ${ }^{89}$ Meanwhile, this condition will block role of governments to control medicine prices. ${ }^{90}$

Another abuse of power through TRIPS regulation can be seen through the exploitation of the Neem tree in India for technology and science purposes. ${ }^{91}$ Research and development divisions of multinational companies use biotechnology to extract the most beneficial ingredient of the Indian sacred tree. ${ }^{92}$ Researchers have traveled around the world and gathered material from different regions (in this case India) to produce new drugs. ${ }^{93}$ Then, they have collected information on beneficial plants and animals and the traditional knowledge of local people. ${ }^{94}$ Unfortunately, after researchers used knowledge from Indigenous people in India to produce useful drugs and sell the drugs worldwide, the profits from 'stealing' natural resources from countries did not flow back to India and other states that have provided similar resources. ${ }^{95}$ These immoral activities of, 'gathering genetic material in a foreign country, (analysing) it, (registering) it, and (earning) a profit from its commercial use,' is an ultimate legal construct below TRIPS. ${ }^{96}$

Multinational companies have used this 'expanded scope of patentability' to cover their 'invention' and have subordinated Indigenous knowledge regarding these substances (Shiva 2004:666; Marden 1999: 289). ${ }^{97}$ This subordination is because the IPR acknowledgement is based on a written piece of evidence, whilst Indigenous knowledge forms are not bound by such procedure. ${ }^{98}$ The existing patent system has allowed the ownership of the design of living organisms through 'genetic engineering'. ${ }^{99}$ The 'discovery' of any substance that has been known to Indigenous people for many years can be granted a patent and

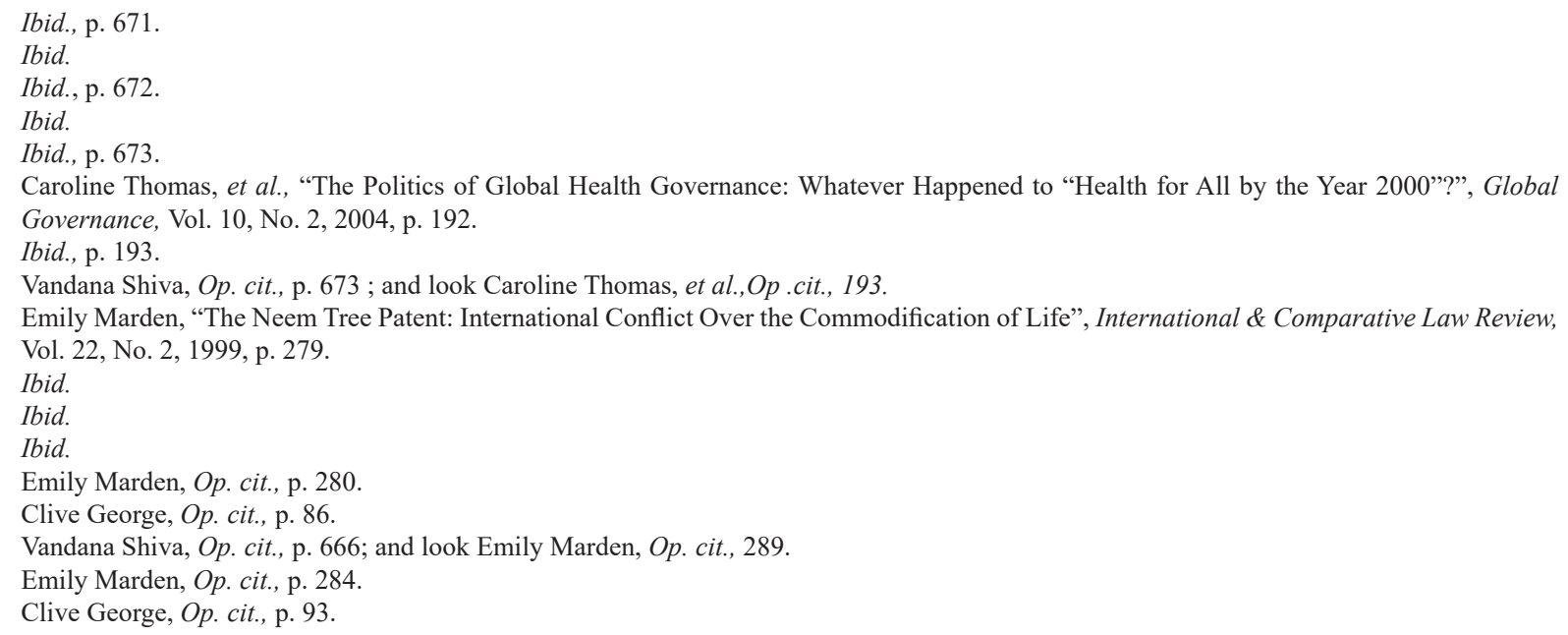


can be claimed by the first company, who register it with a patent or record it in writing. ${ }^{100}$ Moreover, the IPR regime continues, according to Emily Marden, 'to create mechanisms for draining wealth out of the developing countries and least developed countries'. ${ }^{101}$ Neglecting Indigenous knowledge and communal rights through the western IPR regime may only benefit developed countries, who uphold individual rights for patenting and allow injustice for Indigenous communities. ${ }^{102}$ Therefore, one of the development implications of TRIPS is that they exacerbate the unequal conditions between developed and developing countries. This contradicts the WTO's 'pro-development framework' and prioritises the interests of developed countries at the expense of conditions within developing countries.

Maintaining international economic growth as a focus in the Doha 'Pro-development' Round failed to balance the position between developed and developing countries in global trade regimes. The 'pro-development framework' in the Doha Round does not favour developing countries, since developed countries, through their dominance in negotiation processes, have shifted the trade liberalisation framework to benefit themselves. ${ }^{103}$ Their dominant position has created the conditions within which they can easily negotiate the outcome of the declaration to benefit their trade regime. ${ }^{104}$ In contrast, this shifted outcome has caused 'strong alienation' for the majority of developing countries. ${ }^{105}$ The 'pro-development' framework that is supposed to strengthen the position of developing countries and least developed countries in global trade has been subverted and manipulated for the sake of developed countries' corporations. ${ }^{106}$

This round has set a clear example of how developed countries in the WTO have used their dominance to pursue a liberal development agenda for their benefit; the promotion of economic growth through structural adjustment of national economies, trade liberalisation and investment through MNCs. ${ }^{107}$ This emerges as the public transcript of the Doha Round. ${ }^{108}$ The public transcript of the 'pro-development agenda' from the WTO was used as a pulling factor on developing countries to maintain their participation in the world trade regime. ${ }^{109}$ This strategy is a tendency from powerful actors to act and speak differently to hide their real intentions. ${ }^{110} \mathrm{~A}$ translation of this dominance regarding development reflects their interest to create hegemony and may negate 'other' hidden transcripts. ${ }^{111}$ This maintains, and, is exemplary of "organised violence. ${ }^{112}$

These hidden transcripts convey development occurring through inequality. ${ }^{113}$ The basis of the WTO's 'pro-development framework' are neoliberal principles. This is problematic because it merely focuses on "material development" without considering the environmental and societal impacts of these principles in developing countries. The inequality between scientific achievement from developed countries and 'typically communal, folk knowledge of developing countries' can be seen from the Neem tree case. ${ }^{114}$ Therefore, the unequal bargaining position between developed countries (as the first inventor of patented goods) and the

00 Ibid.

101 Emily Marden, Op. cit., p. 287.

102 Emily Marden, Op. cit., p. 289.

103 John Madeley, Op. cit., p. 68.

${ }^{04}$ Ibid.

05 Ibid.

106 Ibid.

07 Caroline Thomas, et al., Op. cit., p. 193.

108 Clive George, Op. cit., p. viii.

109 J. Michael Finger, Op. cit., p. 888.

11 James C. Scott, 1985, Weapons of the Weak: Everyday Forms of Peasant Resistance, Yale University Press, New Heaven, p. 288

11 Ibid., p. 46.

12 Clive George, Op. cit., p. 150.

113 Richard Higgott, et al., Op. cit., p. 437.

114 Emily Marden, Op. cit., p. 282. 
government of India can be seen from the failure to keep the balance between public interest and corporate greed in medicine industry. ${ }^{115}$ In addition, the TRIPS agreement as the big issue in The Doha round has exacerbated the gap between advanced industrial countries and importer countries, especially in patent regime. ${ }^{116}$

\section{Conclusion}

The promise of help through SDT for developing countries (as the majority of importer country of patented rights) is merely used as the medium with which to prioritise MNCs from developed countries which operate in developing countries. Moreover, instead of focusing on developing countries' benefit and empowerment, the term 'development' is used to perpetuate the dominance of developed countries within a neoliberal trade regime. Moreover, the SDT as the heart of The Doha Round merely ended with the claim of successful practices, without looking the 'real development' for developing countries that which improves equal trade relations.. Consequently, The Doha 'Pro-Development' round and TRIPS failed to move developing countries' needs to the center of trade liberalisation as liberal principles of economic growth primary prevailed. This subsequently ignored the conditions within which this concept of 'development' is realized. The unequal protection between indigenous communities' interests and corporations' greed within TRIPS is strong evidence of how international trade regulation puts social justice below commercial interests.

\section{REFERENCES}

\section{A. Books}

George, Clive, 2010, The Truth about Trade: The Real Impact of Liberalization, Zed Books, London.

Jackson, John H., et al., 2013, Legal Problems of International Economic Relations, West Academic Publishing, Minnesota.

Lester, Simon, et al., 2012, World Trade Law: Text, Materials and Commentary, Hart Publishing, Oxford.

O’ Brien, Robert, et al., 2010, Global Political Economy, London.

Scott, James C., 1985, Weapons of the Weak: Everyday Forms of Peasant Resistance, Yale University Press, New Heaven.

Subedi, Surya P., 2008. International Investment Law: Reconciling Policy and Principle. Hart Publishing, Oxford.

\section{B. Journal Articles}

Ezeani, Elimma, "WTO Post Doha: Trade Deadlocks and Protectionism", Journal of International Trade Law and Policy, Vol. 12, No. 3, 2009.

Finger, J. Michael, "Developing Countries in the WTO System: Applying Robert Hudec's Analysis to the Doha Round", The World Economy, Vol. 31, No. 7, July 2008.

Guzman, Adrew T., "Global Governance and the WTO”, Harvard International Law Journal, Vol. 45, No. 2, 2004.

Hart, Michael, et al., "Special and Differential Treatment and the Doha Development Round", Journal of World Trade, Vol. 37, No. 2.

Higgott, Richard, et al., "GATS in context: development, an evolving lex mercatoria and the Doha Agenda", Review of International Political Economy, Vol. 12, No. 3, August 2005.

\footnotetext{
115 Vandana Shiva, Op. cit., p. 673.

116 Dave Timms, Op. cit., p. 68.
} 
Koopman, Georg, "Doha Development Round Perspectives", Intereconomics, Vol. 40, No. 4, July 2005.

Levine, David P., "Political Economy and the Idea of Development", Review of Political Economy, Vol. 13, No. 4, 2001.

Madeley, John, "Doha Round is on Wrong Track", Appropriate Technology, 2007.

Marden,Emily, “TheNeem TreePatent:International Conflict Over the Commodification of Life", International \& Comparative Law Review, Vol. 22, No. 2, 1999.

Matthews, Duncan, et al., "Bilateral Technical Assistance \& TRIPS: The US, Japan \& The European Communities in Comparative Perspective", The Journal of World Intellectual Property, Vol. 9, No. 6, October 2006.

Senona, Joseph M., "EPAs and the Doha Round: development or discontent", Journal of International Trade Law and Policy, Vol. 8, No. 1, 2009.

Shiva, Vandana, "TRIPS, Human Rights and the Public Domain", The Journal of World Intellectual Property, Vol. 7, No. 5, 2004.

Stiglitz, Joseph E., et al., "A Development-friendly Prioritisation of Doha Round Proposals", The
World Economy, Vol. 28, No. 3, March 2005. Timms, Dave, "Double-dealing in Doha", The Ecologyst, Vol. 32, No. 1, February 2002.

Thomas, Caroline, et al., "The Politics of Global Health Governance: Whatever Happened to "Health for All by the Year 2000"?", Global Governance, Vol. 10, No. 2, 2004.

Weber, Heloise, "Reconstituting the Third World'? Poverty Reduction and Territoriality in Global Politics of Development", Third World Quarterly, Vol. 25, No. 1, 2004.

Weber, Martin, "Competing Political Visions: WTO Governance and Green Politics", Global Environmental Politics, Vol. 1, No. 3, August 2001.

Xin, Ziqiang, et al., "Homo Economicus Belief Inhibits Trust", PLoS ONE, Vol. 8, Issue 10, October 2013

\section{Internet Articles}

World Trade Organization, "Special and Differential Treatment Provisions", https://www.wto. org/english/tratop_eldevel_eldev_special_ differential_provisions_e.htm, accesssed in 8 November 2018.

World Trade Organization, "Fact File", http://www wto.org/english/thewto_e/thewto_e.htm, accesssed in 8 November 2018. 